\title{
A case of a slightly symptomatic exfoliative oesophagitis
}

\author{
Eijiro Ueta, Tatsuya Fujikawa, Atsushi Imagawa
}

Mitoyo General Hospital, Kan-onji, Japan

\section{Correspondence to} Dr Tatsuya Fujikawa, tfujikawa-gi@umin.ac.jp

Accepted 31 July 2015

\section{DESCRIPTION}

A 68-year-old Japanese man annually underwent endoscopic examination of the upper gastrointestinal tract. The latest examination revealed longitudinal sloughing of mucosal casts (which was not detected previously) from the mid-oesophagus to the oesophagogastric junction, with mild redness (figure 1). Endoscopic biopsy of the sloughed casts revealed peeled off oesophageal mucosa without dysplasia. Ten months prior to this examination, the patient had received a diagnosis of cardiogenic embolism and atrial fibrillation at his primary care hospital and was prescribed dabigatran (oral direct thrombin inhibitor) with lansoprazole. He took dabigatran correctly with an adequate amount of water while sitting down. He described his symptoms only after we asked him about digestive problems. He sometimes felt slight chest discomfort a few minutes after taking dabigatran but was not concerned about this mild symptom. We replaced dabigatran with rivaroxaban while continuing lansoprazole, and the symptom disappeared within several days. One month later, endoscopy showed an improvement in the oesophageal mucosa, which now had an almost normal appearance (figure 2).

Dabigatran is increasingly prescribed as an alternative to warfarin. ${ }^{1}$ Dabigatran is formulated with tartaric acid to reduce the variability of its absorption, which depends on $\mathrm{pH}^{1}{ }^{1}$ This acidity may partly explain the risk of dyspeptic symptoms and gastrointestinal bleeding. ${ }^{2}$ The same could be said about the oesophagus. It is likely that exposure of the oesophageal lumen to a strong acid from a dabigatran capsule causes oesophageal lesions such

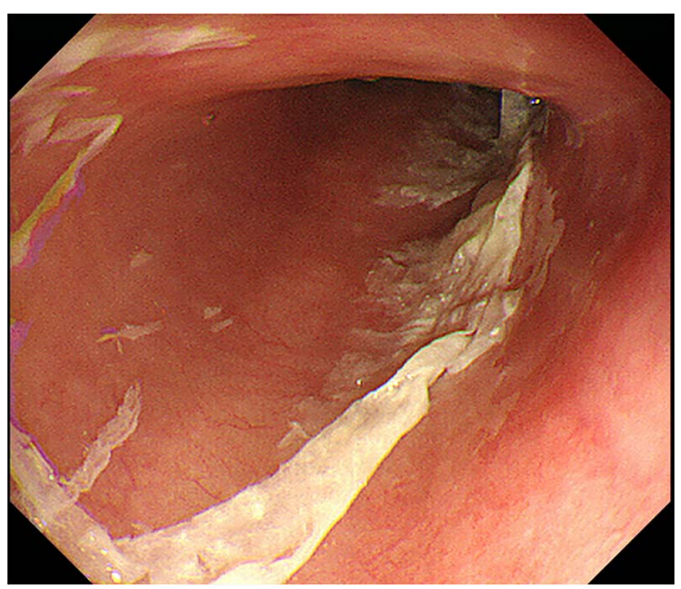

To cite: Ueta E, Fujikawa T, Imagawa A. BMJ Case Rep Published online: [please include Day Month Year] doi:10.1136/bcr-2015211925
CrossMark

\section{Figure 1 Endoscopic imaging of the upper} gastrointestinal tract showing longitudinal sloughing of mucosal casts from the mid-oesophagus to the oesophagogastric junction, with mild redness, suggestive of dabigatran-induced exfoliative oesophagitis.

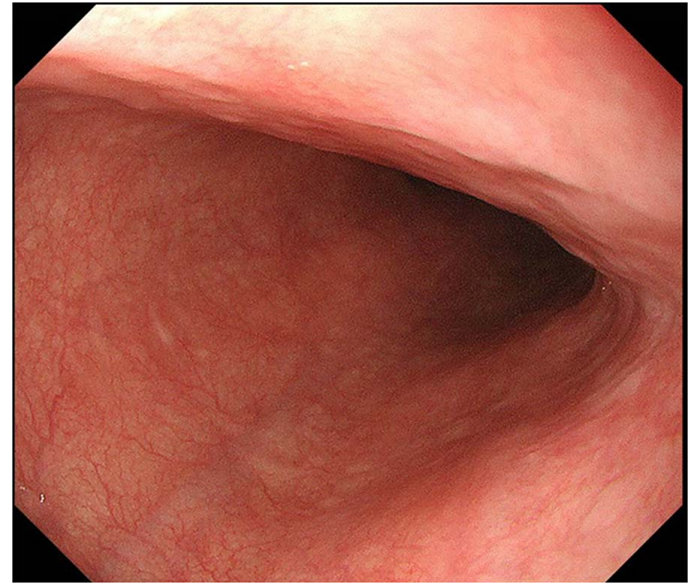

Figure 2 Follow-up endoscopic examination of the upper gastrointestinal tract. The oesophageal mucosa is almost normal, suggesting that the exfoliative oesophagitis resolved.

as exfoliative oesophagitis (as in this case) and oesophageal ulcers. ${ }^{3}$ Even patients who take dabigatran correctly with sufficient water in an upright position $^{3}$ may develop exfoliative oesophagitis. Therefore, physicians should specifically ask patients about digestive symptoms if dabigatran is prescribed; when dabigatran-induced exfoliative oesophagitis is suspected, dabigatran should be replaced with an alternative anticoagulant.

\section{Learning points}

- Dabigatran capsules may cause oesophageal lesions, for example, exfoliative oesophagitis, due to their strong acidity.

- When dabigatran-induced exfoliative oesophagitis is suspected, the appropriateness of dabigatran treatment should be verified; dabigatran may even have to be replaced with a different anticoagulant.

Acknowledgements The authors gratefully acknowledge Dr K Miyatani for the pathological findings.

Contributors EU wrote the manuscript and contributed to the discussion. TF wrote the manuscript and contributed to the discussion. Al contributed to the discussion.

Competing interests None declared.

Patient consent Obtained.

Provenance and peer review Not commissioned; externally peer reviewed 


\section{REFERENCES}

1 Eisert WG, Hauel N, Stangier J, et al. Dabigatran: an oral novel potent reversible nonpeptide inhibitor of thrombin. Arterioscler Thromb Vasc Biol 2010;30:1885-9.
2 Connolly SJ, Ezekowitz MD, Yusuf S, et al. Dabigatran versus warfarin in patients with atrial fibrillation. N Engl J Med 2009;361:1139-51.

3 Okada M, Okada K. Exfoliative esophagitis and esophageal ulcer induced by dabigatran. Endoscopy 2012;44(Suppl 2 UCTN):E23-4.

Copyright 2015 BMJ Publishing Group. All rights reserved. For permission to reuse any of this content visit

http://group.bmj.com/group/rights-licensing/permissions.

BMJ Case Report Fellows may re-use this article for personal use and teaching without any further permission.

Become a Fellow of BMJ Case Reports today and you can:

- Submit as many cases as you like

- Enjoy fast sympathetic peer review and rapid publication of accepted articles

- Access all the published articles

- Re-use any of the published material for personal use and teaching without further permission

For information on Institutional Fellowships contact consortiasales@bmjgroup.com

Visit casereports.bmj.com for more articles like this and to become a Fellow 